Conservation

-

Division of Buildings and

Community Systems

\section{Assessment of the Corrosiveness of Cellulosic Insulating Materials}

\author{
R. Weil and A. Graviano \\ Department of Materials and Metallurgical Engineering \\ Stevens Institute of Technology \\ Hoboken, NJ 07030 \\ Part of \\ The National Program \\ for \\ Building Thermal Envelope Systems and Insulating Materials
}

OAK RIDGE NATIONAL LABORATORY OPERATED BY UNION CARBIDE CORPORATION - FOR THE DEPARTMENT OF ENERGY 


\section{DISCLAIMER}

This report was prepared as an account of work sponsored by an agency of the United States Government. Neither the United States Government nor any agency Thereof, nor any of their employees, makes any warranty, express or implied, or assumes any legal liability or responsibility for the accuracy, completeness, or usefulness of any information, apparatus, product, or process disclosed, or represents that its use would not infringe privately owned rights. Reference herein to any specific commercial product, process, or service by trade name, trademark, manufacturer, or otherwise does not necessarily constitute or imply its endorsement, recommendation, or favoring by the United States Government or any agency thereof. The views and opinions of authors expressed herein do not necessarily state or reflect those of the United States Government or any agency thereof. 


\section{DISCLAIMER}

Portions of this document may be illegible in electronic image products. Images are produced from the best available original document. 
Printed in the United States of America. Available from National Technical Information Service

U.S. Department of Commerce

5285 Port Royal Road, Springfield, Virginia 22161

Price: Printed Copy $\$ 4.50$; Microfiche $\$ 3.00$

This report was prepared as an account of work sponsored by an agency of the United States Government. Neither the United States Government nor any agency thereof, nor any of their employees, contractors, subcontractors, or their employees, makes any warranty, express or implied, nor assumes any legal liability or responsibility for any third party's use or the results of such use of any information, apparatus, product or process disclosed in this report, nor represents that its use by such third party would not infringe privately owned rights. 
ORNL/SUB-7556/I

Dist. Category UC-93, UC-95d

Contract No. W-7405-eng-26

\title{
ASSESSMENT OF THE CORROSIVENESS OF CELLULOSIC INSULATING MATERIALS
}

\author{
R. Weil and A. Graviano \\ Department of Materials and Metallurgical Engineering \\ Stevens. Institute of Technology \\ Hoboken, NJ 07030
}

Part of

The National Program

for

Building Thermal Envelope Systems and Insulating Materials

\begin{abstract}
Research sponsored by the Office of Buildings and Community Systems, U.S. Department of Energy Under Contract W-7405-eng-26 with

Union Carbide Corporation, Nuclear Division

Oak Ridge, Tennessee
\end{abstract}

\author{
Date Published - June 1979 \\ OAK RIDGE NATIONAL LABORATORY \\ Oak Ridge, Tennessee 37830 \\ operated by \\ UNION CARBIDE CORPORATION \\ for the \\ DEPARTMENT OF ENERGY
}




\section{FOREWORD}

This is one of a series of reports to be published describing research, development, and demonstration activities in support of the National Program for Building Thermal Envelope Systems and Insulating Materials. The National Program involves several federal agencies and many other organizations in the public and private sectors who are. addressing the national objective of decreasing energy wastes in the heating and cooling of buildings. Results described in this report are part of the National Program through delegation of management responsibilities for the DOE lead role to the Oak Ridge National Laboratory.

The first annual National Program Plan developed by a team of DOE, NBS, ORNL, and LBL staff was published in January 1979 as DOE/CS0059, available from National Technical Information Service (NTIS), U.S. Department of Commerce, 5285 Port Royal Road, Springfield, Virginia 22161 . The price is $\$ 6.50$.

Ted S. Lundy

Program Manager

Building Thermal Envelope Systems

and Insulating Materials 


\section{SUMMARY}

In order to meet the national goal of insulating $90 \%$ of all houses in the U.S. by 1985, all types of insulation including cellulose will have to be used. Because of flammability and corrosion problems, cellulose is not widely used as insulation. Public Law 95-139 was enacted to set standards for flammability and corrosiveness of cellulosic insulation. The present corrosiveness specifications have several serious drawbacks, namely lack of an established relationship to field conditions and reproducibility of test results. The establishment of a relationship to conditions in walls and attics of houses requires data on corrosion by cellulose in these locations. Another drawback is the relatively long time required to carry out the present tests, which precludes using them for quality control and points to the need of a more rapid testing method. A quantitative test method for corrosiveness of cellulose is also desirable.

This assessment includes a discussion of the information which is available about the corrosiveness of cellulose and other related properties. A survey of the literature dealing with the corrosiveness of wood products other than cellulose and of the corrosiveness in other media by fire-retardant chemicals generally used with cellulosic insulation is included. The types of corrosion which could be caused by cellulosic insulation are briefly discussed.

Recommendations are made to improve the present corrosion-testing procedure. Futher recommendations are made to establish a relationship of the improved test to field conditions. If the present test and field conditions can not be correlated, a new accelerated corrosion test should be designed. The development of a testing method which requires less time and is also more quantitative is also recommended. Research to find less corrosive retardants and substitutes for presently used oncs which may be in short supply in the future is recommended. Studies of the involved corrosion mechanisms should lead to the development of better fire retardants. The establishment of a repository of data on corrosiveness of cellulose, making the data available to interested parties, is also recommended.

\section{INTRODUCTION}

An assessment of the various aspects of the corrosiveness of cellulosic insulation materials is warranted for several reasons. The national goal set by President carter of insulating 90\% of the houses in the Unit.ed States by 1985 seems attainable only if all types of inșulation including cellulose are extensively used. Because of the publicity that corrosion by cellulosic materials 
has rcceived, as well as because of other reasons, there is some reluctance by the public to use this material. Public Law 95-319 was enacted to protect the public from personal injury and property damage resulting from the corrosiveness and flammability of cellulosic materials. This law provides that suitable standards for corrosiveness testing be established. Because of time limitations, the present procedures with some modifications will have to be used. However, the present testing proccdures have drawbacks, particularly their reproducibility and the lack of an established relationship to the field conditions in the walls or attics of houses where insualtion is used. The reproducibility is the morc readily solvahle probleil. Suitable modifications of the present testing procedures can be made to render them more reproducible. The lack of an estahliched relationship to field evililuns is a more long-range problem and is primaxily due to the sparseness of available information on the corrosiveness of cellulosic materials in the walls and attics of houses. When such information becomes available, it will probably be necessary to make substantial modifications to the present test or to formulate a new one so that it reflects the behavior of cellulosic insulation under field conditions on an accelerated basis.

Because of the lack of reliable data, the mechanisms involved in the corrosion of metal components by cellulose are not well understood. The major sources of the corrosiveness of cellulosic insulation are probably the added fire-retardant chemicals when they nicsolvc in molsture to form corrosive media. Provention of corrosion appears therefore to be dependent on the use of less corrosive fire-retardant shemicalo: The least corrosive fire retardants in prcsenl use are the boron cumpounds. While the supply of such compounds as boric acid and borax for use with cellulose appears to be adequate at. present, the pussibility if a future shortage must be considered and suitable substitutes found.

The purpose of this dooument is to bring together the available information which has a bearing on the solution ir the problems associated with the corrosiveness of cellulosic insulating materials. The topius which are considered include the present accelerated corrosion test methods, their shortcomings and possible improvements. The available information about the corrosiveness of cellulogit. materials is prosentiol as are data concerning other pertinent properties. The corrosiveness of other wood products and other insulating materials is also considered. The corrosiveness and fire-retardant properties of chemicals which are or may be used with cellulose is also discussed in this report. The types of corrosion which could be involved are considered too. Finally, various recommendations are presented on how to proceed with the solution of the various problems associated with corrosiveness of cellulosic insulation. 
2. SPECIFICATIONS AND TEST METHOD FOR CORROSIVENESS OF CELLULOSIC

INSULATION.

\subsection{Present Methods}

At the present time there are two principal specifications in the U.S. which include accelerated corrosion testing of cellulosic insulating materials. They are ASTM C739 and HH-I-515D. The corrosion-testing aspects of the earlier federal specification HH-I-515C are the same as C739. There is also a specification N-101-73 of the Cellulosic Insulation Manufacturers Association which is very similar to C739. The sections of C739 and HH-I-515D dealing with corrosiveness of cellulose can be found in Appendix I. Theremay be some changes in the near future in $\mathrm{HH}-\mathrm{I}-515 \mathrm{D}$.

The main differences between $C 739$ and HH-I-515D are:

\begin{tabular}{|c|c|c|}
\hline & $\mathrm{C7} 39$ & $\mathrm{HH}-\mathrm{I}-515 \mathrm{D}$ \\
\hline Humidity \& Temp. & $96 \pm 38 \mathrm{RH}, 120 \pm 3^{\circ} \mathrm{F}$ & $97 \pm 1.5 \% \mathrm{RH}, \quad 120 \pm 1^{\circ} \mathrm{F}$ \\
\hline Aluminum & $2024-T 3$ & 3003, o Temper \\
\hline Steel & low carbon & carbon $<0.3 \%$ \\
\hline $\begin{array}{l}\text { Pretesting } \\
\text { Cleaning }\end{array}$ & $\begin{array}{l}\text { Trichloroethylene } \\
\text { wash }\end{array}$ & $\begin{array}{l}\text { Scrub steel in } 1,1,1 \text {-trichloro- } \\
\text { ethylene, ultrasonic cleaning for } \\
30 \text { min. } 2 \text { distilled water rinses. }\end{array}$ \\
\hline Water Mixing & $\begin{array}{l}20 \mathrm{~g} \text { of insulation with } \\
150 \mathrm{ml} \mathrm{H}_{2} \mathrm{O}\end{array}$ & $\begin{array}{l}\mathrm{m} \ell \text { of } \mathrm{H}_{2} \mathrm{O}=(2.5 / \text { settled density }) \\
\mathrm{x} 150\end{array}$ \\
\hline Exposure Time & $\begin{array}{l}6 \text { days (168 hrs), or } \\
\text { depending on conditions } \\
\text { then for } 30 \text { days }\end{array}$ & 14 days \\
\hline $\begin{array}{l}\text { Post Exposure } \\
\text { Cleaning }\end{array}$ & $\begin{array}{l}\text { no time limit in } \mathrm{HNO}_{3} \\
\text { solution }\end{array}$ & $\begin{array}{l}\text { limits cleaning in } \mathrm{HNO}_{3} \text { solution } \\
\text { to } 60 \text { seconds }\end{array}$ \\
\hline
\end{tabular}

The CIMA N-101-73 procedure differs from C739 in the use of 2024-T3 aluminum and there is no steel coupon to be tested. There appear to be no good reasons for the differences in these tests.

There have been several critiques of the corrosion tests. One criticism pertains to the relationship between the accelerated oorrosion tests and the actual ficld conditions in the walls or attics of buildings. ASTM Spec. C739 states that the accelerated test is intended to duplicate moisture, vapor and chemical migrations to colder areas and condensing of metallic surfaces. However, wilkes stated ${ }^{(1)}$ that both accelerated tests really simulate a roof or 
water-pipe leak. 'l'he corrosion under such conditions is different from that which occurs when water diffuses through the insulation, condenses on metal and evaporates again when climatic conditions change. It has been pointed out (1) that intermittent wetting accelerates the corrosion of steel. in sea water. Mixing the water and the cellulose, as is done in the accelerated tests, also creates different corrosion conditions from those which exist when water diffuses through the insulation and dissolves pieces of solid chemicals already in contact with metal surfaces. Under the latter conditions there are variations in the concentration of the dissolved chemicals over the metal surface creating corrosion cclls wlich can lead to pitting. Air pockets are also more likely to exist in loose-fill insulation than whan the eelluluse is tamped to assure qoodrnntast with lie metal as specified in thc accelerated-test procedures. The accessibility of oxygen also depends on the moisture content. Thus, the degree of differential aexation, which can cause corrosion, can vary between different field conditions and the accelerated tests. There is a clear need to develop a relationship between accelerated tests and field conditions. Probably it will be necessary to modify the accelerated tests or to develop a new one to reflect the field conditions. There are essentially no available corrosion data under field conditions upon which to base the modifications or new tests. Such data have to be gathered first. This task is badly needed. Some tests have been rnnductcd ${ }^{(2)}$ to pelate the accelerated tests with simulatert field condiliums by the so-called wet-and-dry procedure." Metals are also placed initially in ary-fill cellulosıc insulation. Then under highhuminity oonditions, the insulation becomes wet. The results are compared with the usual accelerated corrosion test data. However, the results of these tests have not been puhlished. As part of this assessment, such tests now are being conducted $^{(3)}$.

The accelerated corrosinn tostc are je illarlly directed towards pitting. The pitting type of corrosion is probably the mnat sritical beciuse $1 f$ a pit torms in a gas pipe an explosion can result. Pitting in copper water pipcs leads to leaks. There aro, howevel, vener possible types of corrosion, as will be discussed lator. This accelcrated procedures do not test for thcse other corrosion types.

The accelerated corrosion test procedures have been criticized. The most recent critique ${ }^{(4)}$ is one by the National Bureau of Standaris for the Cunsumer Products Safety Commission. A problem is the reproducibility of the test results. Variations in the humidity have been said ${ }^{(1)}$ to be a major cause of 
the irreproducibility. The requirement for humdity control in HH-I-515D of $\pm 1.5 \%$ is probably not met in most cabinets presently used. Even if it is met at some location in the cabinet, it is unlikely that the humidity is uniform throughout. The $c 739$ specification range of $\pm 3 \%$, while more readily attained, is probably too large and could cause significant variations in the test results. The use of one particular type of humidity cabinet rather than the several presently used, e.g., the closed or air-circulating types, would help to attain more reproducible results. The corrosion conditions in a non-circulating system are probably less severe as the maintenance of a watex layer next to the metal coupon would be an effective barrier to oxygen reaching potential cathodic regions.

The cleaning procedures of the test coupons prior to testing can also affect the results and cause non-reproducibility. It is essential that the cleaning procedure not render the coupon more susceptible to corrosion, e.g., by attacking the metal and causing precursors of pits. The cleaning procedure must also remove all coatings, greases, snils, etc. on the metal surfaces which could affect the test results. The way the coupons are handled for cleaning can also affect the results. If the coupons are bent or deformed, they can become more susceptible to corrosion.

The way the cellulosic insulation is mixed with water can also affect the test results. As already pointed out, corrosion cells can develop if the chemicals are not completely dissolved or if their concentration in the moisture varies over the metal surface. Chemicals with large particle sizes are less likely to completely dissolve during mixing. But then, good dissolution and mixing while probably giving more reproducible results does not reflect the corrosiveness under field conditions.

'lhe relluval of the oorrosion products so that the coupon can be examined for perforations presents a problem. The nitric-acid dips can cause pitting after the exposure has been completed ${ }^{(5)}$. The specification of a time limit in HH-I-515D and use of corrosion inhibitors are attempts to remedy the problem. Several methods for xemoving the corrosion products which are less likely to cause pitting themselves have been proposed.

There are other possible reasons for the poor reproducibility of the test results. Variations in the chloride-ion conlent within one lot of cellulose have been reported ${ }^{(6)}$. The density of the cellulose varies with the type of wood from which it comes. The composition and amount of ink can have an effect and can vary within a given lot of material. Small pieces of metal have been 
found in cellulose ${ }^{(7)}$. If such a metal piece is in contact with the test coupon, pitting can result due to the galvanic reactions. These effccts also need to be investigated.

Another criticism of the accelerated corrosion tests is their relatively high cost and the need for them to be conducted at an outside laboratory. The high costs of the tests result in infrequent testing. Also during the seven to thirty-day time perind involved in conducting a corrosion test, it is likely there have been considerable changes in the product. The fact that the requirements for testing and the procedures differ for cellulose from those of other kinds of jnallation is considered to be unfair by the cellulosic insulation industry. The problem of unqualified laboratories conducting corrosion tests will probahly he helpcd by lle secent anclusion of corxosion testing in the NVLAP (National Voluntary Laboratory Accreditation) Program (8).

The protection of the consumer requires a testing procedure, so that when the product passes it, there is assurance of safety under field conditions. such a test procedure would thus help to establish confidence. Reproducible test procedures are required to prevent the selertion of laboraturies where passing the tests is easier than in others. The same procedure or at least a greater degree of uniformity in testing the different types of insulation is highly desirable and should be possible if the accelerated test reflects the field conditions. Also a less oxponoive arul faster test is needed $\left.{ }^{(}\right)$. These needs are recognized in the National pruyram plan (10) in which the promulgation of performance criteria and standards has been assigned a $\mathrm{c}$ priorily. However, the higher pliusity 1tems, the safety and health of occupants, preservation against deterioration and consumer protection are clearly related to the rnrresion tcat piucelures. 'The problem with the test methods are recognized specifically in the National Proqram plan (10) which slales in section 2.7.1.3 "Available corrosion tests for insulation are not adpirale, arc ditficult to conduct and interpret in a consistent manner, and are sperified for only certain materials. There are presently separate ASTM sorrooion LesLs for mineral wool and cellulose insulation specifications. A new test method and procedure preferably applicahle to all thcrmal iusulation matesidls, needs to be developer and uscd to quantify the immediate and cumulative corrosive effects or lack thereof. We need to klow effects of temperature, moisture, and chemical additives on corrosion rates and mechanisms. The new test method should be applicable rur. short- and long-range corrosion for all metals used in buildings lo which insulation may come into contact. 
The corrosive actions prompted by the fire retardants in cellulosic insulation are not fully recognized and require a systematic study. In addition, an assessment and field studies are needed to document the incidents that are reported in the media (Washington Post, Oct. 1, 1977) and that are common household discussion topics. These should be conducted simultaneously with evaluations of other properties such as fire-retardant longevity. As a minimum, metals investigated should include construction steels, aluminum, and copper."

\subsection{Other Possible Test Methods}

There are two quantitative corrosion testing procedures which may be applicable to ccllulosic insulation. One procedure is the electrical-resistance method which is marketed under the name corrosometer. It consists of an exposed sensing clement made of the metal to be tested. As the element corrodes, its cross-sectional area decreases as does its electrical conductivity. The resistance can be readily converted into a corrosion rate. This method could be used in both wet and initially dry-fill insulation and could be used for corrosion monitoring under ficld location. There are some disadvantages, however. General rather than pitting corrosion rates are measured. Also the electrical. conductivity is affected by mechanical strain and temperature.

The use of a linear polarization technique is a second quantitative method. It is commercially available as the corrator system as well as by several other names. The Stern and Geary ${ }^{(12)}$ relationship showed that the corrosion current can be extropolated from the slopes of a linear relationship between overpotential and the logarithm of the current. This relationship is the basis of the test method. When a siilall potential increment $\pm \Delta E$ is applied to a corroding metal component the current flowing through the external circuit by which the potential is applied, changes by $\pm \Delta \mathrm{I}$. This quantity $\Delta \mathrm{I}$ is proportional to the corrosion rate. The corrosion rate can be determined very quickly. Ilowcvar, it ran only be used when the electrical conductivity of the corrosive medium is sufficiently high. The method could be used in wet cellulose, but not in dry.fill. During an accclerated corrosion test, the method could be used to measure rates and if this quantity can be related to pass or fail, the test duration could be markedly reduced from the present 14 days. The method could then also be used for quality control during manufacture of cellulosic insulation. The method would be unsuitable for monitoring corrosion under field conditions because of the low electrical conductivity of the relatively dry insulation.

The electrical-resistance method was used ${ }^{(13)}$ to study the corrosion characteristics of fire-retardant wood. The probes were placed in watercxtract solutions and with wöd at $120^{\circ} \mathrm{F}$ and $9 n \%$ relative humidity (RH) after 
treatmeat with fire retardants. Considerable variation in the results and poor correlation to other methods were found. A 95-hour immersion period using low-carbon steel probes gave the best results. The variation in the results was partly laid to possible surface contamination of the metal probes. In some preliminary tests conducted at stevens ${ }^{(3)}$, the steel electrical resistance probes were placed in four lots of dry-fill cellulosic insulation together with steel gas pipes in a humidity cabinet under the conditions of HH-I-515D. Some correlations of the corrosion rates and the degree of corrosion of the steel pipe as visually observed were noted.

\section{DATA CUNCERNING THE CORROSIVENESS OF CELLULOSE}

The published data concerning the corrosivencss uf velluiosic insulating materials are very sparse. There are undoubtedly data in the hands of llidrufaçtureis and installcrs. Meaus of gathering this information and making it available are needed. Specific cases of corrosion by cellulosic insulating materials are listed in a report by a subcommittce of lle IIS House of Representatives (14). Cellulose insulation caused corrosion of pipes and electrical wiring in 30 condominimum units while under construction in Tiburon, CA. The same product was allegedly responsible for corrosion of snetal piping, wiring and outlet boxes in 13 town houses in Pleasantown, CA. A warehouse in which cheeses had been stored collapsed in Wisconsin in 1975 due to corrosion of ateel Irames. 'l'he corrosion was attributed to cortain firc relaxdants, in these cases ammonium sulfate, in cellulosic insulation. The same product was also inplicated in corrosion of steel frames in about half of other similar builuings examined. Mobile homes in Michigan showed pitting corrosion on outside walls which was attributed to cellulose insulation. Cellulose was reported to have caused copper piping to corrode in Rochelle, IL three years after installation.

There have also been reports of corrosion in the newspapers (15). Tho abovc cases have been cited as well as other incidents. It has been reported that the reaclion of moisture with ammonium sulfate, used as a fire retardant to give sulfuric acịd is a primary cause of osrroeion. Aluminum sulfate used as a substitute fire retardant for non-availatile Luron compounls was saj.d (15) to have caused corrosion of water pipes in Flordia. Mobile homes in Canada have also experienced corxosion due to cellulosic insulation (16).

A survey of the cellulosic insulation ${ }^{(17)}$ industry appears to indicate that therp is no corrosiun problem. Only one out of 27 companies surveyed indicated that there were any corrosion problems. It is also interesting 
that none of the respondents of the survey, who listed the fire retardants which they used, mentioned ammonium sulfate.

Recent reports by or for US government agencies concerned with insulation deal only briefly with corrosiveness. An assessment made by Dynatech. R/D Co. ( states that the lack of information available on corrosion is mainly due to the absence of a suitable test. Their discussion of building codes in the us did not mention corrosion. The Federal Trade Commission report on Labelling and Advertisement of Home Insulation (18) took cognizance of the corrosion problems and cited a report of the Massachusetts Energy office that the commonly used fire retardants can cause corrosion. The report ${ }^{(18)}$ also raised the.question as to whether corrosion affects the thermal performance of the insulation. In the Minessota Retrofit Insulation In-Situ Test Program (19) corrosion was not a studied property. In this study in which the walls and ceilings of houses were opened and the existing insulation studied, out of 55 locations, in only one (Wall No. 25) was there a finding of corrosion at a sheathing due to wetness resulting from the removal of a downspout. Examination of flexible metal conduits, ceiling back boxes behind surface-mounted lights and tube and post wiring was said to have shown no degragation which should include corrosion. The examination for corrosion was, however, recommended in future studies as was the placing of corrosion-test coupons in wall and attic insulation for periodic examination.

Some accelerated corrosion-test results involving cellulosic insulation are contained in a "Survey of Cellulosic Insulating Materials"(20). The main findings were that corrosion was not uniform over the coupon surface, being probably greatest at points of intimate contact between metal and cellulose. A similar finding was made in tests conducted at stevens ${ }^{(3)}$ in which it was found that snpper. water pipes buried in dry-fill insulation and then placed in a high humidity corroded more on the bottom surfaces where their weight resulted probably in better contact with the cellulose. Shen (5) found preferential corrosion of steel coupons at air pockets. Anderson and Wilkes (20) found that in general the corrosiun rates were greater for steel, than for enpper or aluminum but varied considerably. The correlation of the corrosion rates to the composition of the fire retardant or the $\mathrm{pH}$ was poor. it was pointed out that a general currosion rate of $0.45 \mathrm{~mm}$ per year would dissolve a $0.003-$ inch thick coupon in 30 days (i.e., $0.96 \mathrm{~mm} /$ year or 0.38 inches/year would dissolve the coupon in the 14-day test). Some samples exhibited such high corrosion rates. Of course, local pitting would result from a much lower rate. The aluminum coupons showed significant pitting in the tests reported 
by Anderson and Wilkes (20). Extensive subsurface, intergranular corrosion was also observed for some aluminum coupons.

In more recent accelerated corrosion tests ${ }^{(7)}$, which were performed essentially as specified by HH-I-515D, 55 lots of cellulose obtained in diffexent locations through the US were tested. No correlation of corrosiveness as measured by the acrelerated test and the $\mathrm{pH}$ of the cellulose was found. of the 55 samples of cellulose tested, only 8 passed the test for all the metals, i.e., steel, copper and aluminum. Attempts to determine the chemical nature of the fire retardants were also made. A trend was noted in that no samples nassed the tesl whlch contained either ammonium or aluminum sulfate as fire retardants. Of the 8 samples which passed the test, 7 contained a form of hnrax ac file ieldedanes, 3 boric acid, and 1 cach ammonium dihydrogen phosphate and calcium carhonate, recpcctively. Some samples containcd seveld fire retardants.

4. PROPERTIES OF CELLULOSE RELATED TO CORROSIVENESS

\subsection{Fire Retardancy}

The types of fire-retardant chemicals mixed with the cellulose have an important effect on corrosiveness. Boric acid and borax have been extensively used as a fire retardant because they suppress char fnrmation and afteryluw (21). However, due to recent shortages nf horen nnmpindk, uthey Ellemicals are being used. The chemicals found in insulal iun by wilkes (7) are boric acid $\left[\mathrm{H}_{3} \mathrm{BO}_{3}\right]$, borax $\left[\mathrm{Na}_{2} \mathrm{~B}_{4} \mathrm{O}_{7} \times 5 \mathrm{H}_{2} \mathrm{O}\right.$ or $\left.\mathrm{Na}_{2} \mathrm{~B}_{1} \mathrm{O}_{7} \times 1 \mathrm{NH}_{2} \mathrm{O}\right]$, aluminum sulfate $\left.\left[\mathrm{A}_{2}\left(S \mathrm{~N}_{1}\right]\right] \times 18 \mathrm{H}_{2} \mathrm{O}\right]$, dilum 1 um silfate $\left[\left(\mathrm{NH}_{4}\right)_{2} \mathrm{SO}_{4}\right]$, drmonium dihydrogen phosphate $\left[\left(\mathrm{NH}_{4}\right) \mathrm{H}_{2} \mathrm{PO}_{4}\right]$, calcium carbonate $\left[\mathrm{CaCO}_{3}\right]$, calcium sulfate [ $\mathrm{CaSO}_{4} \times 2 \mathrm{H}_{2} \mathrm{O}$, and sodium calcium

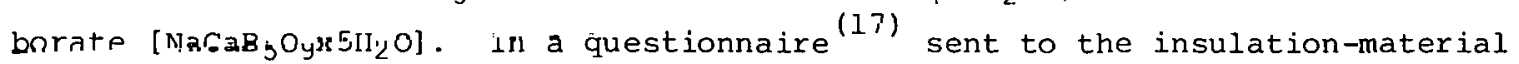
industry, information about the type nf fire rctardonl used was requested.

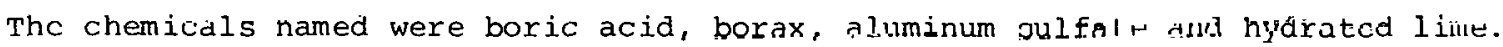
Bramhall (22) classified the least expensive and most effective rnmmonly uxcd chemicals as ammonium compounds (phosphales, sulfates and halides), boron compounds (boric acid, borax) and rinr sompounds (wlilulue and sulfate). In a recent poll conduster in conjunctiril with the celluluse $\perp$ conference in St. Louis in June $1978^{(23)}$, a shortage of boron compounds was anticipated in the future. Therefore, studics to find suitable substitute fire-retardant chemicals are needed. Towards this end a survey of available information is provided here. The literature contains a number of chemical formulations for making wood products more fire retardant. Moffett ${ }^{(24)}$ described a treatment for shredded 
wood fiber using water, ammonium sulfate, boric acid, potassium alum and a diamine derivative dye of triphenyl methane. Nunomura, et al. (25) found that diammonium phosphate and ammonium chloride lowered the decomposition temperature of cellulose, while boric acid increased it. A process for improving the smolder resistance of cellulose ${ }^{(26)}$ was patented. It consists of treating the material with vapors of a mixture of methanol, boric acid, methyl borate and water.

A treatment of cellulose with the product of the addition of $\mathrm{H}_{2} \mathrm{SO}_{4}$ to borate ores was said ${ }^{(27)}$ to improve fire retardancy. Sulfur is claimed to be a better smolder retardant than boric acid ${ }^{(28)}$. Thus combining about $2-9 \%$ sulfur with other fire-retardant chemical mixtures was said to render them morc effective. Studies using tunnels, fire tubes and modified Schlyter panels to determine fire retardancy indicated that monoammonium phosphate was better than zinc chloride in low concentrations ${ }^{(29)}$. Higher amounts of zinc chloride were more effective. Boron compounds also became more effective in higher concentrations. Sodium chloride and sodium dichromate were not effective. Ammoniumpolyphosphate liquid fertilizer was said to be an effective fire retardant for wood $(30)$. A boric-acid-disodium-octaborate mixture was reported ${ }^{(31)}$ to be a very effective fire retardant.

\subsection{Moisture Content.}

The amount of moisture absorbed by the cellulosic insulation greatly effects its corrosiveness. Under conditions of low moisture content, corrosion is very likely not a problem. Therefore, one way to alleviate the corrosion problem is to limlt the accessibility to moisture by propex building design. ASTM Specification C739 states that the cellulose shall not have a weight increase of more than $15 \%$ in 24 hours when the $\mathrm{RH}$ is raised from $50 \%$ to $90 \%$ at $120^{\circ} \mathrm{F}$. Samples of cellulose tested ${ }^{(7)}$ for weight gain due to moisture absorption showed values varying from $3.5 \%$ to $38 \%$. There appears to be a critical RH for moisture absorption ${ }^{(32)}$. This RH varies for different salts. Below this RH, corrosion should be minimal. The moisture absorption rate also changes with time (7). In some cases there may even be a weight loss at a later time indicative of moisture being given off by the celluluse. The rates in one day are also not necessaxily indicative of moisture absorption over more prolonged periods. Some samples which had a weight gain of less than 158 in one day, showed a very high absorption rate after 5 days ${ }^{(7)}$. The moisture absorption depends on the type, amount and particle size of the chemicals added. Some chemicals are more hygroscopic than others. Ammonium and aluminum sulfate appear to be quite hygroscopic (7). 
The moisture absorption rate and the rate at which moisture diffuses through the insulation to reach the metal surface obviously affects the corrosiveness. The diffusion of moisture through the insulation is related to air movement and the relative humidity. In some preliminary tests (3), it was found that when metals are covered with dry-fill cellulosic insulation, there is an incubation period before any corrosion, as measured by a resistance probe, occurs. This period probably represents the time it takes for sufficient moisture to reach the metal surfaces through the insulation.

\section{$4.3 \mathrm{pH}$}

T:1 general, corrosion rates depend on $\mathrm{pH}$. The measured $\mathrm{pH}$ in wet insulation varies greatly ${ }^{(7)}$ and as already mentioned, it does not seem to be dirertily rclatal lu cuprosion. The pH probably varies locally with concentration of the added chemicals and their solution rates. Also the measuseu pH may be different from that in the vicinity of the corroding metal.

\section{4 Other Properties}

The particle size of the fire-retardant chemicals affects corrosion in that large pieces result in locally high concentration when they dissolve leading to concentration cells. Separation of the clellulose from the fire retardants is also more likely if their particle size is large. The method by which the cellulose and fire retardants are mixed can affect corrosivenrss. Dry mixing, which is the most commonly used method, leats to particles being in contact with the metal under field conditions and the development of concentration cells when the chemicals are dissolved in moisture. Such conditions are less likely when such mixing processes as spraying or misting are used. However, these processes also have disarvantages in that the mists must be contairled to protect the operators from breathing the chemicals.

The relative quantities of chemicals added to the cellulnse can alco affect: corrogiveness. Generally, the quantity is about $20 \%$ by weight. Recently, to pass the fire-retarding tests, the amounts have probably been increased. The greater the amount of each chemical added, the higher itc oonesmliallun in moisture and probably the greater the $1 \mathrm{ikelihood} \mathrm{of} \mathrm{mil-miform} \mathrm{distribution.}$ The relative amounts of fire-retardant chemicals to cellulose also have to be maintained uniformly. Otherwise thc test data are meaningless. 
5. CORROSIVENESS DATA CONCERNING OTHER WOOD PRODUCTS AND INSULATING MATER IALS.

There have been several corrosion studies of metals in contact with wood products other than cellulose, some of which had also been made fire retardant. The metals usually were in the form of nails or other fasteners. Corrosion of these metal parts was said ${ }^{(33)}$ to be due to the acidity of most woods when moist. The acid dissolved the protective oxide formed around metal parts. The relative humidity was an important factor in that the corrosion rate was faster when the $\mathrm{RH}$ was greater than $80 \%$. The acid vapors which woods emit can also corrode metals $(33)$.

Some corrosion tests ${ }^{(34)}$ involved steel and brass bolts in cypress boards, impregnated with several fire-retardant chemicals, in 95-100\% RH. Ammoniumphosphate-treated boards badly corroded the bolts. Steel was also badly corroded, while brass only slightly attacked in ammonium-sulfate-treated wood. When both ammonium sulfate and phosphate were used, the corrosion was less severe and the products were easily removed. In ammonium-alum-treated wood, the effect was like that in ammonium sulfate. Aluminum sulfate resulted in slight corrosion of steel and hardly any attack on brass bolts. A control sample in wood without fire retardant showed about the same effect as the aluminum-sulfate-treated materials.

When galvanized steel and brass fasteners were embedded in pine treated with zinc chloride, it appeared that with sufficient moisture, corrosion was more severe ${ }^{(35)}$ than in untreated wood. The addition of sodium dichromate accelerated corrosion when the $\mathrm{RH}$ was hi.gh. At $90 \% \mathrm{RH}$, brass showed dezincification. The effect of various treatments of the metal surfaces on their corrosion in moist wood buried in the ground at various temperatures was also investigated $^{(3 \hbar)}$. Cadmium and nickel-plated stecl recieted corrnainn hetter than steel which was galvanized, paxkerized or coated with resin or Duco cement. Galvanized staples were found to be more corrosion resistant than plain ones after remaining in pine posts for 8 years ${ }^{(37)}$. The posts treated with copper sulfate and sodium dichromate corroded the metal most severely, while a treatment with a water solution of zinc sulfate and arsenic acid followed by sodium dichromate gave the best results.

Steel, brass and aluminum strips sandwiched between wood blocks treated with fire retardants and kept at $40^{\circ} \mathrm{C}$ and $95 \% \mathrm{RH}$ showed ${ }^{(38)}$ that borax treatment resulted in a corrosion rate of $0.72 \mathrm{mils} /$ year for steel compared to 
$21.9 \mathrm{mils} /$ year when the fire retardant was ammonium sulfate. Boric acid, diammonium phosphate, and a mixture of boron compounds gave corrosion rates of less than $4 \mathrm{mils} /$ year. Placement of various nails in wood treated with either ammoniated copper arsenite (ACA) or chromated copper arsenite (CCA), showed that type 304 or 306 stainless steel exhibited the least corrosion (39). Monel nails pitted in CCA, but behaved well in ACA. Aluminum, zine, cadmium or tin-cadmiull coatings on steel were ineffective in preventing corrosion.

At elevated temperatures, vapors given off by wood can corrode metals ${ }^{(40)}$. vapors of such compounds as formic acid, acetic acid and formaldehyde can be corrosive. Pyrolysis pronducte from wood (40) can also be corrosive.

Therc are relatively few data available on the corrosiveness of other insulating materials. Rigid polinurcthane fudll $1 \mathrm{ll}$ a warm and humid envirnnment was found to be corrosive to mild steel, but not to aluminum and copper (41). Sume tests involving fire-retardant additions were also reported. Glass fiber, rock-wool insulation and cellulose were subjected to both ASTM C739 and the HH-I-1030A accelerated tests ${ }^{(5)}$. (The C\%39 test is for cellulose and the HH-I-1030A is for mineral wood.) In the C739 test using steel coupons, all 18 lots of cellulose failed, i.e., there were perforations, as did all 4 lots of the mineral wool and all 3 lots of glass fiber. The aluminum coupons failed in one lot of glass fiber, in two of mineral wool and in nine cellulose lots. Using the HH-I-IO3OA test with steel sommns, ald ocllulose failed, while the mineral wool and glass-fiber lots passed. The failure of the cellulose was attributed to its hygroscopy. Shen ${ }^{(6)}$ also oluserved in dry tests (HH-I-1030n is a dry test) that hygroscopic chemicals added to cellulose accelerated corrosion when compared to the wet test.

b. CORROSIVENESS OF FIRE RETARDANT CHEMICALS IN OTHER MEDIA.

There are some data of corrosiveness in other media of the fire retardants which axe used with cellulosic insulation. These other media are generally aqueous solutions. The available data can be summarized as follows ${ }^{(42-46)}$.

\subsection{Steel}

6.1 .1 Boric acid - At concentrations below $20 \%$ the corrocion rnt.e is 20 to $50 \mathrm{mils} /$ year. At conccntrations of 20-90\% corrosion rates are greater than $50 \mathrm{mils} / \mathrm{yr}$.

6.1.2 Borax - Rate is between 5 and $50 \mathrm{mils} / \mathrm{yr}$ in. all concentraliuns and at temperaturee to $100^{\circ} \mathrm{C}$. 
6.1.3 Ammonium Sulfate - At concentrations below 40\%, the corrosion rate is greater than $50 \mathrm{mils} / \mathrm{yr}$ at $15^{\circ} \mathrm{C}$, decreases to about $20 \mathrm{mils} / \mathrm{yr}$ at $25^{\circ} \mathrm{C}$ and then increases to $50 \mathrm{mils} / \mathrm{yr}$ at $50^{\circ} \mathrm{C}$. The lowest rate occurs at $25^{\circ} \mathrm{C}$ at a concentration of $30 \%$.

6.1.4 Aluminum sulfate - Corrosion rate exceeds $50 \mathrm{mils} / \mathrm{yr}$.

6.1 .5 Calcium sulfate - At low concentration (10\%) the rate varies between 5 and $10 \mathrm{mils} / \mathrm{yr}$.

\subsection{Copper}

6.2.1 Boric acid - Rate is less than $20 \mathrm{mils} / \mathrm{yr}$.

6.2.2 Borax - Rate is less than $20 \mathrm{mils} / \mathrm{yr}$.

6.2.3 Ammonium Sulfate - Rate is greater than $50 \mathrm{mils} / \mathrm{yr}$ at $15^{\circ} \mathrm{C}$ and between 20 and $50 \mathrm{mils} / \mathrm{yr}$ at $25^{\circ} \mathrm{C}$.

6.2.4 Aluminum sulfate - Rate is less than $20 \mathrm{mils} / \mathrm{yr}$.

6.2.5 Calcium sulfate - At $10 \%$ concentration and $25^{\circ} \mathrm{C}$, rate exceeds $50 \mathrm{mils} / \mathrm{yr}$. In saturated solutions rate is less than $20 \mathrm{mils} / \mathrm{yr}$.

\subsection{Aluminum}

6.3.1 Boric acid - At $25^{\circ} \mathrm{C}$ and 208 concentration, rate is less than $2 \mathrm{mils} / \mathrm{yr}$. At $60^{\circ} \mathrm{C}$, rate is less than $20 \mathrm{mils} / \mathrm{yr}$. At $100^{\circ} \mathrm{C}$, rate exceeds $50 \mathrm{mils} / \mathrm{yr}$.

6.3.2 Borax - Some attack at $80^{\circ} \mathrm{C}$, little at lower temperatures.

6.3.3 Ammonium sulfate - Some attack with pitting. Attack increases with increasing temperatures. Rate exceeds $50 \mathrm{mils} / \mathrm{yr}$.

6.3.4 Aluminum sulfate - At $25^{\circ} \mathrm{C}$, rate is less than $2 \mathrm{mils} / \mathrm{yr}$. Somewhat higher in very concentrated solutions and at higher temperatures.

6.3.5 Calcium sulfate - Saturated solutions cause little attàck. Lrower concentrations cause somewhat higher rates, but less than $20 \mathrm{mils} / \mathrm{yr}$.

6.3.6 Diammonium phosphate - Highly corrosive. Attack decreases with time.

6.3.7 Aluminum trihydrate - Probably very little attack other pertinent results ${ }^{(34)}$ are that sodium dichromate provides some corrosion protection. However, in solutions containing mono and diammonium phosphate, the corrosion of steel and galvanized steel is accelerated by sodium-dichromate additions. Sodium carbonate, which is used to adjust the "pH" of cellulose material, appears not to be detrimental as far as corrosiveness is concerned. While the corrosive conditions in cellulosic insulation are quite different from those in aqueous media, the abuve data indicates that the results from water solutions may be used as a guide to selecting less corrosive fire retardants. 
6.4 Corrosion inhibitors for steel, copper and aluminum.

In the selection of fire retardants, their corrosiveness has to be considered. Chemicals which act as both fire retardants and corrosion inhibitors are obviously desirable additives to cellulose. A list of corrosion inhibitors used in aqueous media as found in the literature is presented in Table 1 . Some of the chemicals are probably not suitable as fire retardants and in some cases, data on fire retardancy is not available. Again the data is provided to aid in the selection of chemicals to make the cellulose less corrosive.

\section{TABLE 1}

\begin{tabular}{|c|c|c|c|}
\hline INHIBITOR COMPOSITION & MED I UM & $\begin{array}{l}\text { METAL TO BE } \\
\text { PR.OTECTED }\end{array}$ & REF \\
\hline $5 \times 1 n^{-4}$ Pntassium Diohromale & . LIN sódium Carbonate & Aluminum & 47 \\
\hline $\begin{array}{l}\text { Hydrogen Peroxide, Borax, and } \\
\text { Digodium Hydroyen Fhosphate }\end{array}$ & - IN Sodium Carbonate & Aluminum & 87 \\
\hline Chromates & $\begin{array}{l}\text { Sulfate \& Chloride } \\
\text { solutions at pH } 7\end{array}$ & Aluminum & 48 \\
\hline Silicates \& Nicotonic Acid & $\begin{array}{l}\text { Strong Alkaline or } \\
\text { Acid Sulutions }\end{array}$ & Aluminum & 18 \\
\hline $\begin{array}{l}0.5 \mathrm{~g} / \mathrm{l} \text { Sodium Silicate and } \\
2 \mathrm{~g} / \mathrm{l} \text { Sodium Dichromate }\end{array}$ & $\begin{array}{l}\text { Sulfate Solutions } \\
\text { (containing chlorides) } \\
\text { at } \mathrm{pH} \mathrm{ll}\end{array}$ & Aluminum & 48 \\
\hline Chromates & Conc. Sulfuric Acld & Aluminum & 49 \\
\hline $0.5 \%$ Sodium Chromate & $20 \%$ Phosphoric Acid & Aluminum & 50 \\
\hline 1: Sodium Chromate & 20-80\% Phosphoric Acid & Aluminum & 50 \\
\hline 5\% Sodium Chromate & Conc. Sulfuric Acid & A.1uminum & 50 \\
\hline Sodium Fluusillcate & $\begin{array}{l}\text { Dilute sorium } \\
\text { Carbonale }\end{array}$ & Aluminum & 50 \\
\hline $0.2 \%$ Sodium Silicate & I8 Sodium Carbonate & Aluminum & 50 \\
\hline Borates & $\begin{array}{l}\text { Glycol-Water Cooling } \\
\text { Solutions }\end{array}$ & Aluminum & 50 \\
\hline Soluble silicates & $\begin{array}{l}\text { Sodium or Potassium } \\
\text { Carbonate Solutions }\end{array}$ & Aluminum & 51 \\
\hline Sodium Fluosilicate & Dilute Soda Ash & $\begin{array}{l}\text { Aluminum, Copper, } \\
\text { and falvanized } \\
\text { Steel }\end{array}$ & 52 \\
\hline $0.5-1 \div$ Fluoride $\left(\mathrm{NH}_{4} \mathrm{~F}\right.$ or $\left.\mathrm{NH}_{1} \mathrm{HF}_{2}\right)$ & $\begin{array}{l}\text { liq Ammonium niliyils } \\
\text { gen Phosphate } 8 \text { 10\% } \\
\text { Ammonium Nitrate at } \\
\text { pH } \leq 7\end{array}$ & $\begin{array}{l}\text { Aluminum-Base } \\
\text { Alloys }\end{array}$ & 53 \\
\hline $\begin{array}{l}\text { Mono and Diammonium Phosphate } \\
\text { Mixture }\end{array}$ & $\begin{array}{l}20 \% \text { Ammonium Nitrate } \\
\text { and } 1 \% \text { Ammonia }\end{array}$ & Aluminum & 54 \\
\hline $\begin{array}{l}\text { Borax, Borjer Atin le ofyanle } \\
\text { Salts of } \mathrm{H}_{2} \mathrm{BO}_{3}\end{array}$ & $\begin{array}{l}20-30 \% \mathrm{NH}_{4} \mathrm{NO}_{3} \text { With } 15 \% \\
\mathrm{H}_{2} \mathrm{O} \text { and Ammonium } \\
\text { Hydroxide }\end{array}$ & $\begin{array}{l}\text { Aluminum and } \\
\text { Aluminum Alloys }\end{array}$ & 55 \\
\hline Carbonates and Sulfates & Aqueous Ammonia & $\begin{array}{l}\text { Impure Aluminum or } \\
\text { Aluminum Alloys }\end{array}$ & 56 \\
\hline $\begin{array}{l}\text { Hydorxides of } \mathrm{K}, \mathrm{Li}, \mathrm{Na}, \text { Hydra- } \\
\text { zine \& Morpholine }\end{array}$ & Boric Ncid & Carbon steels & 57 \\
\hline Sodium Arsenite & & $\begin{array}{l}\text { 99: Aluminum and } \\
\text { Al-Mg Alloy } \\
(98 \% \mathrm{Al})\end{array}$ & 58 \\
\hline
\end{tabular}


TABLE 1 (CONT'D.)

\begin{tabular}{|c|c|c|c|}
\hline INHIBITOR COMPOSITION & MED IUM & $\begin{array}{l}\text { METAL TO BE } \\
\text { PROTECTED }\end{array}$ & REF \\
\hline $\begin{array}{l}<0.5 \mathrm{M} \text { Benzotriazole, 8-Hydroxy- } \\
\text { quinoline, \& 8-Mercaptoquinoline }\end{array}$ & $\begin{array}{l}\text { in } \mathrm{NH}_{4} \mathrm{Cl} \text { and in } \\
\left(\mathrm{NH}_{4}\right)_{2} \mathrm{SO}_{4}\end{array}$ & $\begin{array}{l}\text { M-1 Electrolytic } \\
\text { Copper }\end{array}$ & 59 \\
\hline Iodide Ions & Acidic Solutions & Copper & 60 \\
\hline 2-4 Dinitrophenyl Hydrazine & in Sulfuric Acid & Copper & 61 \\
\hline Sodium Dichromate & $\begin{array}{l}\text { Air Conditioning } \\
\text { Systems }\end{array}$ & $\begin{array}{l}\text { Ferrous sheets \& } \\
\text { Pipes }\end{array}$ & 62 \\
\hline $\begin{array}{l}\mathrm{H}_{3} \mathrm{PO}_{4} \text {, Ca Superphosphate and } \\
\text { Bisuperphosphate of Lime }\end{array}$ & $\begin{array}{l}\left(\mathrm{NH}_{4}\right)_{2} \mathrm{SO}_{2}, \mathrm{CaCl}_{2} \text {, } \\
\mathrm{MgCl}_{2} \text { and Urea }\end{array}$ & Carbon Steels & 63 \\
\hline $\begin{array}{l}5 \text { ppm Mercaptobenzoticiazole, } \\
3 \text { ppm } \mathrm{H}_{3} \mathrm{PO}_{4} \text {, \& Methylphosphoric } \\
\text { Acid }\end{array}$ & $\begin{array}{l}714 \mathrm{ppm} \mathrm{CaSO}_{4} \cdot 2 \mathrm{H}_{2} \mathrm{O} \\
519 \mathrm{ppm} \mathrm{MgSO}_{4} \cdot 7 \mathrm{H}_{2} \mathrm{O} \\
185 \mathrm{ppm} \mathrm{NaHCO}_{3} \text { and } \\
989 \mathrm{ppm} \mathrm{NaCl}\end{array}$ & $\begin{array}{l}\text { Steel, Copper and } \\
\text { Brass }\end{array}$ & 64 \\
\hline $\begin{array}{l}\text { Borax + Mercaptobenzotriazole } \\
+ \text { Sodium Metasilicate + Lime } \\
\end{array}$ & $\begin{array}{l}\text { Cooling System of Car } \\
\text { Engine }\end{array}$ & $\begin{array}{l}\text { Brass, Aluminum, } \\
\text { Cast Iron }\end{array}$ & 65 \\
\hline $\begin{array}{l}\text { Benzotriazole \& } 2 \text { Mercaptobenzo- } \\
\text { triazole with Nitrate-Borax }\end{array}$ & $\begin{array}{l}\text { Closed Rerirculating } \\
\text { Water Systems }(\mathrm{pH}=7)\end{array}$ & $\begin{array}{l}\text { Copper and Steel } \\
\text { Surfaces }\end{array}$ & 66 \\
\hline Benzotriazole & $\begin{array}{l}\text { Aqueous Acid, Neutral } \\
\& \text { Alkal ine Solutions }\end{array}$ & Copper & 67 \\
\hline Aldehydes & Hydrochloric Acid & Aluminum & 68 \\
\hline Organic Acids & Hydrochloric Acid & Stepl. & 69 \\
\hline Pyridines, quinolines & Sulfuric ACid & Iron & $70-74$ \\
\hline Onium Ions & Sulfuric Acid & Iron & 75,76 \\
\hline $\begin{array}{l}\text { Piperidines, Pyrocidines \& } \\
\text { Pyrimidines (Saturated \& Partially } \\
\text { Saturated) }\end{array}$ & Acids & Steel & 77 \\
\hline $\begin{array}{l}\text { Aldehyde-Amine Condensation } \\
\text { Products }\end{array}$ & Hydrochloric Acid & Mild Steel & 78,79 \\
\hline Cyand-Ethylated Amines & Sulfuric Acid & Iron & 80 \\
\hline Stearyl Amine & Acids & Iron & 81 \\
\hline Organic Sulfides & Sulfuric Acid & Iron & 82,83 \\
\hline N-2-Propynyl Morphol ine & Acids & Iron & 84 \\
\hline Cyclic \& Heterocyclic Ketoamines & Acids & Iron & 85 \\
\hline Xanthates & Acids & Iron & 86 \\
\hline Aryl and Alkyl Sulfoxides & Acids & Iron & 87 \\
\hline Thiouxeas & Sulfuric Acid & Iron & $88-91$ \\
\hline Thioureas & AC 1ds & Nluminum & .92 \\
\hline Thioureas & Acids & Trron & $93-96$ \\
\hline Organic Thiocyanates & $\begin{array}{l}\text { Hydrochloric and } \\
\text { Sulfuric Acid }\end{array}$ & Iron & 97,98 \\
\hline $\begin{array}{l}\text { Thiazoles, Thiazines, Propylene } \\
\text { Oxide Adducts of Thiourea }\end{array}$ & Sulfuric Acid & Iron & 99 \\
\hline Halogenated Aromatics & Acids & Iron & 100 \\
\hline Chlorinated Amines & Acids & Iron & 101 \\
\hline 2-Mercaptobenzotriazole & Gylcol Antifreezes & $\begin{array}{l}\text { Copper and Copper } \\
\text { Alloys }\end{array}$ & 102 \\
\hline
\end{tabular}




\section{TYPES OF CORROSION TO BE CONSIDERED}

In view of the fact that there are so few data available abrut corrosion under field conditions, it is very difficult to make an assessment about the types of corrosion which are prevalent and therefore should be considered. Unfortunately, the cases where failures due to corrosion by cellulose occurred were apparently not examined by experts. No data about the type of corrosion are available. Levinson (2) listed several types of corrosion as being possible. It appears that pitting corrosion is the most serious, as failures can result from this type very rapidly. A small pit in a gas pipe can cause a leak and an explosion with resulting injuries or loss of life. Pitting in water pipes can cause leaks into walls. The accelerated tests are apparently intended primarily for pitting.

Uniform corrosive attack takes longer than pitting to cause failure. Uniform attack probably occurs, but local hole formation is the more serious. Galvanic corrosion, due to couples of dissimilar metals can also occur. The most likely causes are small metal pieces, which have been found ${ }^{(7)}$ in cellulose, making contact with pipes or other metal components in walls or attics. It is less likely in view of the poor electrical conductivity of cellulose insulation, even when damp, that an appreciable corrosion current would flow between pipes or other articles made of different metals in ceilings or walls even if they are in relative close proximity. If the insulation is very wet and the dissimilax metals are very close toqether. galvanir sorroeion could oceur. If they already touch, they would corrode even without the cellulose. Stress corrosion again would not be due primarily to the cellulose. For it to occur, the metal part would have lu be under stress. If metal parts, esperially rnpnox and al.uminum alloys are under stress, some of the fire retardants used in cellulose could Lause them tó tal $\perp$ by this type of corrosion. As already pointed out, one can speculate about the type of corrosion that would occur. What is needed is to have someone who is familiar with the differcnt types af un usion oxumine metal parts which fail, become visible or are removed in field studies.

8. RECOMMENDATIONS

\subsection{Corrosion Testing}

8.1.1 'lhe present accelerated-test proceduxe should be modified to make the results more reproducible. Various recommendations for attaining this ohjective should be examined and the workable ones adopted. Further. study of the factors leading to the poor rcproducibilily is also needed.

8.1.2 The ASTM C739 and GSA HH-I-515D specifications should be identical. The existance of several versions of HH-I-515D must also be avoided. 
8.1.3 Research and data gathering should proceed to relate the accelerated tests with field conditions. All field tests, including the opening of walls of houses and the insulation of test houses should be conducted so as to maximize the obtained corrosion data. Simulated field tests should also be conducted towards the above purpose.

8.1.4 If the correlation of the present tests to field conditions is poor, work toward designing a new test should begin.

8.1.5 Test procedures which are less expensive and of shorter time duration should be developed even if these methods are not adoptable as actual specifications. A quantitative tests is highly desirable.

8.1.6 It is also highly desirable that there be the same corrosiveness test for the different types of insulating materials.

\subsection{Development of Less Corrosive Cellulosic Insulation}

8.2.1 Research and development of less corrosive fire retardants are needed.

8.2.2 Chemicals which act as both fire retardants and corrosion inhibitors are desired.

8.2.3 Substitutes for the boron compounds, for which a shortage may develop, should be developed.

8.2.4 Better uniformity of the chemicals added to cellulose is needed.

8.2.5 ' Studies of the corrosion mechanisms involved are needed to optimize the development and also to aid in 7.1.

8.2.6 Studies to find means of 1 imiting the accessibility of the cellulose to moisture by better housing design and other possible methods are needer as the corrosion problem would probably be insignificant in the absence of moisture.

\subsection{Establishment of Data Repository}

Cunsiderablc data abnut rnrrosion exist and should be gathered. Steps should be taken also to encourage manufacturers, builiers, housing inspectors, etc. to provide the data. The data should then be made generally available. 


\section{REFERENCES}

1. P. Wilkes, Corrosiveness Test Procedure, Proc. Cellulose I Conferences, St. Louis, MO, 1978.

2. I. Levinson, Corrosiveness - State of the Art, Ibid.

3. R. Weil and A. Graviano, Unpublished data.

4. J. Clifton, J. Grimes, M. C. Goddett and J. P. Brown, Critique of Corrosion Test Methods, NBS, 1.979.

5. Test Methods for Evaluating Corrosiveness of Building Insulation, Naval Weapon Support Center, Crane, Indiana, 1977.

6. K. K. Shen, Some Problems Concerning the Corrosion Tests of Cellulose Insulating Materials, Thermal Insulation Conference, Tampa, FL, 1978.

7. Cellulose Thermal Insulation, Naval Weapons Support Center Report, Crane, Indiana, 1978 .

8. First Annual Report - National Voluntary Jahoratory nccredilation program, U.S. Uepartment of Commerce, 1977.

9. An Assessment of Thermal Insulating Materials and Systems For Building Applications, BNL-50862, 1978.

10. National Program Plä For Building Thermal Envelope Systems and Insulating Matexials, office of Conservation and Solar Application, Dept. of Energy and NBS, Dept. of Commerce, 1979.

11. J. Morel, Ontario Research Foundatinn, Mississauga, Ontario, Canada, private Comunication, 1978.

12. M. Stern and A. L. Geary, J. Electrochem. Soc., 104, 56, 1957.

13. C. C. Peters and H. W. Bickiner, Evaluation of Several Methods For Determining the Corrnsivenese of Fire Retardant-Treated woud, Forest Products Lab., U.S. Dept. of Agriculture, Madison, WI.

14. Home Insulation, Report by Subrnmm, on ovcroight aill Investigations of the Comm. on Interstate and Foreign Commerce, House of Rep., 95th Congress, 2nd Session, 1978.

15. M. Miner and L. Ingreassia, The Washington Post, E6, Oct. 1, 1977.

16. N. Wright, Thermocomfort, St. Thnmas, Sanada, Trivale cumlunicátıon, 1978.

17. Questionnaire - Survey of the Building Tnșlation Industry, [ynatcoh R/D Co., Lumbridge, MA, 1978 (unpublished).

18. Labelling and Advertising of Home Insulation, Final staff Report to FTC and proposed Trade Regulation (16 CER Part 460), Bur. of Consumer Protection, 1978.

19. Minesota Retrnfit Inculation Tr-Situ 1rogram, HCP/W 2843-91, 1978 .

20. R. W. Anderson and P. Wilkes, Survey of Cellulosic Insulation Materials, ERDA $77-23,1977$.

21. J. G. Bower, RSI: Roofing/Siding/Insulation, 55 (3), 92, 1978.

22. G. Bramhal.l, Wood Fire Behavior and Fire-Retardant Treatment, Canadian Wood Council, Ottawa, Can., 1966.

23. Results of Survey and Questionnaire, Cellulose I Conference, St. Louis, MO, 1978. 
24. R. S. Moffett, U.S. Patent 3,027,326, 1962 .

25. A. Numomura, I. Hidetake, A. Kasi, and K. Komazawa, Hokkaiddritsu Sinsan Shinkenjo Kenkyu Hokoku, 57, 1972.

26. N. B. Knoepfler, J. P. Madacsi, and J. P. Neumeyer, U.S. Patent 4,012,507, 1975.

27. S. M. Draganov, U.S. Patent 3,983,040, 1976.

28. R. J. McCarter, U.S. Patent Appl. 870,385, 1978.

29. H. W. Eickner and E. L. Schaffer, Fire.Technology, 3, 90, 1967.

30. H. W. Eickner, J. M. Stinson, and J. E. Jordan, Proc. Amer. Wood-Preservers Association, 65, 260, 1969.

31. A. D. Syska, Forget Service Research Note, FPL-0201, U.S. Dept. of Argriculture, Madicon, WI, 1969.

32. J. D. Sinclair, J. Electrochem. Soc., 125, 734, 1978.

33. R. H. Farmer, Chemistry in the Uti,lization of Wood, Chap. 7, Pergamon Press, NY, 1967.

34. A. Van Kleeck, Proc. Amer. Wood-Preservers Association, 38, 160, 1942.

35. R. H. Baeckler, Proc. Amer. Wood-Preservers Association, 45, 390, 1949.

36. R, D. Graham, M. M. Wilson, and A. Oteng-Amoako, Wood-Metal Corrosion: An Annotat.ed Survey, For. Res. Lab., School of For., Uregon State Univ., Res. Bull. 21, No. 72, 19, 1976.

37. Ibid, No. $73,19,1976$.

38. J. C. Middleton, S. M. Draganov, and F. T. Winters, Forest Products Journal, $15,463,1965$.

39. R. D. Graham, M. M. Wilson, and A. Oteng-Amoako, Wood-Metal Corrosion: An Annotated Survey, For. Res. Lab., School of For., Oregon State Univ., Res. Bull. 21, No. 15, 7, 1976.

40. D, Knotkova-Ceramakova and J. Vlckova, British Corrosion Journal, 6, 17 , 1971.

41. L. S. Van Delinder and C. J. Hilado, Journal of Cellular Plastics, 11, $25 \mathrm{Jan} / \mathrm{Feb}, 1.975$.

42. N. E. Hamner, Corrosion Data Survey, N.A.C.E., Houston, TX, 1974.

43. P. Schweitzer, Corrosion Resistance Tables, Dekker, NY, 1976.

44. L. D. Yates, Corrosion Tests of Metals and Ceramics, Tennessee Valley Authority, Chem. Engr. Report No. 9, Wilson Dam, AL, 1951.

45. R. J. Schmitt, The Use of Iron, Carbon Steel, and Alloy Steel in the Chem. Industry, From Proceedings Short Course on Process Industry Corrosion, rollege of Eng̣r., Ohio State Univ., Tech. Group Comm. T-5, 31, 1960.

46. K. F. Miller, R. S. Treseder, and A. Wachter, Corrosion, 10, 7, 1954.

47. I. A. Ammar, M. A. Solimann, and S. Esasasa, Corrosion Prevention and Control, 10, 35, 1963.

48. H. Richaud, Corrosion Science, 4, 191, 1964.

49. H. Lichtenberg, Aluminum, 20, 264, 1938. 
50. A. H. Roebuck and J. F. Richards, Corrosion Inhibitors for Aluminum, International Corrosion Forum, Paper No. 134, NACE, Toronto, Ontario, Can., 1975.

51. V. F. Neguv, A. M. Kyazimov, and Z. M. Sultanova, Salamzade. Azerb. Neft. Khori, 45, 19, 1966.

52. J. F. Thomas, Canadian Journal of Research, 21B, 43, 1943.

53. G. B. Funkhouser, U.S. Patent 3,099,819, 1963.

54. E. W. Harvey, U.S. Patent 2,855,286, 1959.

55. W. E. Standord and R. D. Miller, U.S. Patent 3,033,670, 1962 .

56. A. Mathiaschitz, N. Mertaul, and E. Sacher, Austrian Patent 215,248, 1961.

57. N. N. Nak'kina, L. S, Zhuravlpv, anir v. v. Shishilev, Teprlenteyeidka, 18, $84, .1971$.

58. J. L. 'l'alati. and B. M. Pater, Indian Tumrnal nf Tosh., 1, 310, 1 JGG.

59. V. P. Dobrovol'shaya and V. I. Skxyabina, Khim. Teknol. (Kharkov), 24, 117,1971 .

60. S. M. Mayanna and T. H. V. Setty, Corrosion Science, 14, 691, 1974.

61. S. Siddagangappa, S. M. Mayanna, and F. Pushdanadan, Anti-Corrosion, 23, $11,1976$.

62. C. M. Sterne, Proc. ASTM, 35, 261, 1935.

63. N. Ohsako and T. Tsuno, Japan Kokai, 64 44,946, April 27, 1974.

64. C. W. Hwa and J. T. Jacob, Ger. Offen. 2,528,551, 1976.

65. J. Ovlat, British Corrosion Journal, 3, 190, 1968.

66. Trade Literature, Terh. Rul1, 53,., Shorwin Williäilis Clutll, INew YOYK, NY.

67. R. Walker, Cullustur, 29, 2yU, $19 \% 3$.

68. M. N. Desai and S. M. Desai, Werkstuffe Korrosion, 17, 207, 1966.

69. A. M. Lulua, 1. N. Pitilova, and E. N. Chislova, Zh. Prikl. Khim., 41, 286, 1968.

70. L. Felloni and A. Cozzi, Ann. Univ. Ferrard, 5 Cz. 5, Suppl. 4, 253, 1966.

71. R. M. Hudson, Q. L. Cooney, and C. J. Warning, British Corrosion . Tnurnal, 2, 81,1957 .

72. F. F. Clishko, Yu.A. Mirgorod, V. S. Kutsur, 'I'. I. Lisina and T. A. Feldman, Zh. Prik. Khim, 41, 1140, 1968.

73. H. Tamura, Y. Matsuda, and M. I. Jima, Kogyo Kagaku Zasshi, 72, 1077, 1969.

74. K. S. Lee, Daehan Awahak Hwnejee, 13, 1.3, 1969.

75. V. P. Grigor'ev, and V. V. Kuznetsov, Zashch. Metal., 4, 203, 1968.

76. J. W. Lorenz and H. Fischer, Ann. Univ. Ferrara, Sez. 5, Chim. Pura Appl., Suppl. 4, 81, 1966.

77. V. P., Grigor'ev and V. V. Kuz.jnetsov, Zashch. Metal., 3, 178, 1967.

78. V. N. Dolinkin, M. A. Korshnov, and V. I. Makimova, Uch. Zap. Yaroslva Teknol. Inst., 9, 160, 1966. 
79. V. F. Negreev, A. M. Kyazimov, and N. N. Kyazimova, Mater. Nauch. Tekh. Soveshch. Zasach. Korroz. Oberudovaniya Neft. Gazov. Skvazhin, Baku, 23, 1964 .

80. B. Naumann, M. Fischer, K. Schwabe, and R. Mayer, German (East) 69,251 (Cl. C23f) Oct. 5, 1969 .

81. R. Tournier, Fr. 1,533,399 (Cl. C23g), July 19, 1968.

82. F. Zucchi, G. Trabanelli, and G. Gullini, Electrochim. Metal., 3, 407, 1968 .

83. O. Radavici, Ann. Univ. Ferrara, Sez. 5, Suppl. 4, 449, 1966.

84. C. W. Lutz, U.S. Patent 3,345,296, Oct. 3, 1967.

85. G. S. Gardner and A. J. Saukaitis, U.S. Patent 2,768,970, Aug: 14, 1956.

86. V. Sourek, J. Nemcova, and J. Pálesek, Korose Ochrana Mater., 9, 92, 1965.

87. G. Trabanelli, F. Zucchi, G. Gullini, and r. Vittorio, British Corrosion Journal, 4, 212, 1969.

88. A. S. Afanas'ev, V. I, Sotnikova and Yu.S. Pashuta, Ukr. Khim. Zh., 29, $1316,1963$.

89. B. Anilin, Fr. 1, 577, 626, Aug. 8, 1969.

90. S. Ammar and S. Darwish, Corrosion Science, 7, 579, 1967.

91. J. Heidemeyer and H. Kresche, Corrosion Science, 8, 377, 1968.

92. R. A. Porwancher and K. M. Beck, Ger. Offen. 1,949,399, June 4, 1970.

93. B. Analin Und Soda Fabrik, Fr. 1,577,597, Aug. 8, 1969.

94. Y. V. Fedorov, M. V. Uzlyuk, and V. M. Zelenin, Zashch. Metal., 6, 311, 1970 .

95. I. I. Antropov, G. G. Vrzhosek, G. I. Dremova, V. F. Pauasenko, and I. S. Pogrevova, Zashch. Metal., 6, 440, 1970.

96. F. Hovemann, Ger. Offen. 1,936,538, Jan. 28, 1971.

97. S. P. Miskidzh'yan; U. V. Fedorov, M. V. Uzlyuk, G. G. Vrzhosek, G. I. Dremova, and L. I. Antropov, Zasch. Metal., 9, 520, 1968.

98. Y. Fedorov, S. P. Miskidzh'yan, A. M. Pinus, and M. V. Uzlyrk, Zashch. Metal., 7. 73, 1971.

99. I. O. Larsonneur, U.S. Patent 3,440,095, April 22, 1969.

100. Z."A. Foroulis, U.S. Patent 3,459,654, Aug. 5, 1969.

101. H. Tamura, Y. Matsuca, Y. Kinuhata, M. Okahara, and S. Komori, Kogyo Kagaku 2455Hl, 73, 438, 1970.

102. W. S. Calcot.t, U.S. Patent 1,797,401, March 24, 1931. 
7.7 Corrosiveness-The composition of the matexial shall be such that no corrosion of metal building materials shall occur when tcsted in accordance with 10.7 .

10.7 Corrosiveness:

10.7.1 Scope-The insulation material shall be tested to determine the corrosive properties resulting from water and moisture vapor acting on the fibers, migrating varying amounts of chemical constitutions to the insulation surfaces which may react with metal sidings and other metallic building materials. It ahould be notcd that this is an accelerated test intended to duplicate moisture vapor and chemical migration to colder areas and condensing of metallic surfaces.

10.7.2 Apparatus and Materials:

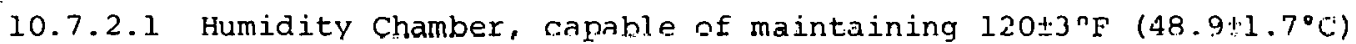
and $9613 \%$ relarive humidity.

10.7.2.2 Crystallizing Dishes, two, $90 \mathrm{~mm}$ diameter by $50 \mathrm{~mm}$ high.

10.7.2.3 Test specimens, two each, 2 by 2 -in. (50.8 by 50.8 mun) by $0.0003-$ in. $(0.162-\mathrm{mm})$ thick metal free of tears, punctures, or crimps as follows:

(1.) 2024-T3 Bare Aluminum

(2) ASTM B 142, Type ETP, Cabra No. 110, soft copper.

(3) Tow-carbon, commercial quality, cold rolled, shim steel.

10.7.3 Specimen-A representative sample of the insulation shall be submitted for test, portions of which shall be used for each test.

10.7.4 Procedure:

10.7.4.1 Wash the metal specimens with trichloroethylene to remove any oil or grease. Dry at room temperature.

10.7.4.2 Pre-saturate the insulation samples by mixing $20 \mathrm{~g}$ of insulation with $150 \mathrm{ml}$ of distilled water at room temperature for each test specimen.

10.7.4.3 Place a 1/2-inch $(12.7-\mathrm{mm})$ thick layer of saturated insulation into the $90 \times 50$ evaporating dish, tamp level and place metal specimen. Cover the metal specimen with the remaining insulation and tamp to assure good contact with the metal plate. Cover with nonmetallic screen to prevent spilling during test.

10.7.4.4 Place the composite specimens and a control metal specimen into the humidity chamber, calibrated at $1.20^{\circ} \mathrm{F}\left(489^{\circ} \mathrm{F}\right)$ and $96 \pm 38$ relative humidity, for $168 \mathrm{~h}$.

1U.7.4.5 Upon completion of the test, thoroughly wash the metal specimens under running water and lightly brush them to remove loose corrosion products. Remove the remaining corrosion products by immersing them in 10 parts distilled water and 1 part nitric acid, $15.9 \mathrm{~N}$. Rinse the samples in water and dry.

10.7.4.6 Make two duplicate tests for each determination.

10.7.5 Report-The report shall include the following:

10.7.5.1 Temperature, relative humidity, and exposure time. 
10.7.5.2 Comparision of corrosion between insulated panel and control panel. When minor surface etching occurs on the insulated aluminum or copper panels, extended 30-day tests must be conducted to determine additional corrosion effect. Extended 30-day tests are conducted on the steel panel only when corrosion of the insulated steel panel compares unfavorably with that of the control steel panel.

10.7.5.3 Noncorrosiveness shall be determined by the absence of any perforations when the metal specimen is observed over a chrome reflected 40-W appliance light bulb.

$\underline{\mathrm{HH}-\mathrm{I}-515 \mathrm{D}}$

The pertinent sections of HH-I-515D which deal with corrosion are:

3.1.7 Corrosiveness. The loose fill insulation material shall be tested for corrosiveness as specifjed in 4.8.5. The composition of the insulation material shall be such that after testing; no perforation of the $3 \mathrm{mil}$ metal specimens shall be evident when the specimens are observed over a chrome reflected 40-W appliance light bulb.

4.8.5 Corrosiveness. Determination of corrosion shall be in accordance with the following test procedure: (see 3.1.7).

\section{APYAKA'IUS AND MATERIALS:}

Humidity chamber capable of maintaining $120^{\circ} \pm 1^{\circ} \mathrm{F}$ and a relative humidity of $97 \pm 1.5$ percent.

Evaporating dishes: Six, glass, $90 \mathrm{~mm}$ diameter by $50 \mathrm{~mm}$ height.

Test specimens: Two each, 2 by 2 inches $(50.8 \mathrm{~mm})$ by 0.003 inch $(0.0762 \mathrm{~mm})$ thick metal free of tears, punctures, or crimps as follows:

(1) 3003 bare aluminum, zero temper.

(2) ASTM B 152, type ETP, Cabra No. 110. soft copper.

(3) Low carbon, commercial quality, cold rolled, less than 30 carbon content, shim steel.

Insulation Sample: Samples of the loose fill thermal insulation submitted for test.

Procedure: Degrease the steel coupons until completely free of water-breaks by scrubbing in 1,1,1-trichloroethane followed by ultrasonic cleaning in a fresh portion of the same solvent for 30 minutes. Rinse in at least two successive portions of distilled water or deionized water (galss containers only) and drain to inspect for water-breaks. Hot air dry. Handle degreased coupons only with clean forceps. Presaturate the insulation samples by mixing 20 grams (gms) of insulation with distilled water. The quantity of distilled water to be used for each $20 \mathrm{~g}$ sample shall be determined using, the following formula:

$$
\text { ml distilled water }=\frac{\cdots}{\text { determined settled density (pcf) }} \times 150
$$

For each $20 \mathrm{~g}$ sample of presaturated insulation, place approximately one-half of the insulation sample into an evaporating dish, tamp level, using a clean stainless steel spatula. Place a metal specimen centered on this one-half sample pad in a horizontal plane. 
Place the remaining half of the presaturated $20 \mathrm{~g}$ insulation sample into the evaporating $\mathrm{dish}$ on the metal specimen and tamp to assure an even distribution of this material and to assure good contact of the insulation with the metal. Do not cover the evaporating dishes. If dripping occurs in the chamber, position a drip guard in the chamber to divert condensation to the chamber floor. Repeat the above for the six specimens of the $3 \mathrm{mil}$ material. Place all six specimens into the chamber preconditioned to $120^{\circ} \mathrm{F} \pm 3^{\circ} \mathrm{F}\left(49^{\circ} \mathrm{C}\right)$ and $97 \pm 1.5$ percent relative humidity) for 14 days.

Upon completion of the test, thoroughly wash the metal specimens under running water and lightly brush them to remove loose corrosion products. Remove the remaining corrosion products from the copper, aluminum and steel specimens by immersing the test specimens in a solution of 10 parts distilled water and 1 part nitric acid, $15.9 \mathrm{~N}$. The samples shall be immersed in the acidrinse no longer than 30 seconds for any period between rinsing and light brushing; and shàl 1 be immersed no more than twice to remove corrosion products and/or cealed inculation materiale.

After cleaning, examine the 0.003 inches aluminum, copper, and steel specimens over a chrome reflected $40 \mathrm{~W}$ appliance light bulk for performation (see $3.1,8$ ). 


\section{ORNL/SUB-7556/ I \\ DISTRIBUTION \\ Dist. Category UC-93,UC-95d}

1. P. R. Achenbach, National Bureau of Standards-Gaithersburg

2. R. J. Adam, Dow Chemical, Midland, Michigan

3. R. W. Anderson, Diversified Insulation, Inc., Hamel, Minnesota

4. E. L. Bales, Stevens Institute of Technology, Hoboken, New Jersey

5. J. Barnhard, Thermal Insulation Manufacturers Association, Mt. Kisco, New York

6. R. W. Beausoliel, National Bureau of Standards-Gaithersburg

7. A. L. Berlad, State University of New York-Stony Brook

8. H. E. Borger, Building Research Advisory Board, Washington, D.C.

9. R. L. Bullock, NIBS, Washington, D.C.

10. G. D. Carber, TVA, Chattanooga, Tennessee

11. H. I. Cohen, Consumer Product Safety Commission, Washington, D.C.

12. W. P. Ellis, H: B. Fuller Company, Spring House, Pennsylvania

13. A. E. Fiorato, Portland Cement Association, Skokie, Illinois

14. G. J. Fitzgerald, SICIM, Washington, D.C.

15. W. S. Fleming, W.S. Fleming \& Associates, Syracuse, New York

16. E. C. Freeman, DOE/BCS

17. J. R. Gracia, DOE/ORO

18. R. F. Hemphill, Tennessee Valley Authority, Chattanooga, Tennessee

19. C. Hollowe11, Lawrence Berkeley Laboratory, Berkeley, California

20. E. Hudson, 6 East 74th St., New York, NY

21. J. G. Hust, NBS-Boulder

22. R. R. Jones, NBS-Gai thersburg

23. T. Kusuda, NBS-Gaithersburg

24. D. Lamb, TVA, Chattanooga, TN

25. S. Launey, DOE/BCS

26. G. Leighton, DOE/BCS

27. K. R. Long, University of Iowa

29. R. G. Mathey, NBS-Gaithersburg

30. J. P. Millihone, DOE/BCS

31. R. J. Ohlemiller, Princeton University

32. S. Petersen, NBS-Gaithersburg

33. W. T. Phelan, Owens Corning Fiberglas, Washington, D.C.

34. F. J. Powell, NBS-Gaithersburg

35. H. Ross, DOE/BCS

36. M. Savitz, DOE/BCS

37. R. Sonderegger, Lawrence Berkeley Laboratory

38. G. J. Teitsma, Dow Chemical Company, Granville, Ohio

39. J. Thompson, State of Oregon Department of Energy, Salem, OR

40. R. P. Tye, Dynatech R/D Company, Cambridge, MA

41. J.P. Verhalen, U.S. Mineral Products, Stanhope, NJ

42. J. L. Weidt, John Weidt Associates, Inc., Chaska, MN

43. R. Weil, Stevens Institute of Technology, Hoboken, NJ

44. P. R. Wilkes, NWSC, Crane, IN

45. L. A. Abbatiello

46. M. Baker

47. R. S. Carlsmith 
47. R. H. Cooper, Jr.

48. F. A. Creswick

49. R. G. Donnelly

50. C. S. Dudney

51. D. M. Eissenberg

52. W. Fulkerson

53. A. R. Hawthorne

54. D. R. Johnson

55. T. S. Lundy

56. M. M. Martin

57. D. L. McElroy

58. J. W. Michel

59. R. E. Minturn

60. J. N. Robinson

61. M. W. Rosenthal

62. A. C. Schaffhauser

63. J. 0. Stiegler

61. D. B. Trauger

65. P. J. Walsh

66. J.R. Weir, Jr.

67. D. J. Wilkes

68-70. Laboratory Records

71. Laboratory Records - RC

72. ORNL Patent Office

73-74. Central Research Library

75. Document Reference Section

76. Assistant Manager, Energy Research \& Development, DOE-ORO

77-449. For distribution as shown in TID-45nก under rategnries US. -93 and UC-95d 